\title{
Albanian language face globalization challenge or developmental trend?
}

\author{
Gladiola Durmishi (Elezi) \\ University of Vlora "Ismail Qemali" \\ gladiola.elezi@yahoo.it
}

DOI:10.5901/mjss.2014.v5n19p626

\begin{abstract}
Language reflects a nation. Language is the clearest view of a nation and its culture. The extent to which the language is enriched and purified is an indicator of the level of this culture. So, national revivals have always gone parallel to the adding elements from the language itself and cleansing of foreign words that have flowed from other language. This is continuing even today ... Cleaning the language from this phenomenon is a scientific and national task. "Albanian language science has appreciated the work done by the best old and renaissance authors for cleaning the Albanian language from unnecessary foreign words. We still continue to make efforts to clear the Albanian literary language in order not to let the values of our language disappear and preserve its connections with the literary language.

Globalization, although it is good for the development of the most undeveloped countries, has turned into a persecution of cultures throughout the world. It seems that Tosk and Geg dialect and Albanian literary language too, will be soon as the precious things we keep in the museum, which are of a great value but useless. Is there a solution to avoid this happening to this beautiful and ancient language? Of course there is. It's up to the government to help preserve mother tongue as it is, as other countries around the world are already doing. The Albanian language is full of foreign words, archaize, regional belonging and atrocities. Globalization is based on society and as a starting point it has the competitiveness. Many analysts in the world, when talking about globalization often recognize that globalization is a human perspective process and as such is inevitable. In order to scrap this division between people, new and accessible ideas should be found. Otherwise this may lead to utopia. What would Gjon Buzuku had thought when he wrote "Meshar"? He wrote this book to tell albanians that Albanian language should be used in religious services, but today we already have many foreign words, neologisms, archaize and regional belonging. Albanian language is facing globalization with both, its positive and negative sides. We should realize that without foreign words Albanian can not survive, but we need a cultural and language policy, a language planning for foreign words and their usage. A policy that would not only end in drafting the principles and criteria, but to put them into use, too. With good planning language can ensure proper integration of foreign words within the language standard, because the standard language only in this way can maintain its identity and integrity.
\end{abstract}

Keywords: globalization, language science, religious service, language planning, identity, integrity, standard , foreign words, neologism, archaism, regional belonging etc.

\section{Globalizms in albanian language, a challenge or a developmental expectation}

Linguistic term globalism includes neologisms, historisms, archaisms, professionalisms, orientalisms as well as borrowing of foreign words on sources of various indio-european languages. Knowing and dealing with globalisms we should maintain an attitude toward them. Globalisms are developmental trends for the necessity of the enriching and "cleaning" albanian language simultaneously. They constitute a challenge e.x. instead of neologisms we can use pretty well the adequate albanian word obtaining the same meaning in the phrase. Typical in the usage of neologisms is the contemporary albanian author Ismail Kadare. To know better the globalisms it is necessary to use borrowing and their sources. The place of the borrowing in the Albanian lexicon :

1. Many foreign words are part of albanian lexicon and we can't substitute them any more.

2. Many borrowing words have a deteriorating overtone

3. It's necessary to make attempts to refrain borrowing of the words from other languages or foreign words to be out of usage, while we have albanian words, fully in the same meaning, most distinguished, precise and clear for albanian speakers. The broad activity of writers, political social activity of people,in art and culture, for cleaning and enriching of standard language, becomes concrete in the substitution of foreign words with albanian words. 
Borrowings can be seen in the way they enter in a language. Are presented in written and spoken form. Our country for a long life history has had relations with other countries as a result have had a strong impact reflected in the albanian lexicon.

1. Words of greek belongings, the earliest borrowings. Words from earlier Greek belong to the social fields, vegetation such as: fern, cabbage, cherry...etc.Some lexical borrowings from greek have remained in spoken language such as regionals and the rest as a usage of outdated words, so historisms.

2.Words of italian belongings: Words from italian in the commerce field, navigation.We can mention some words in the terminology of navigation: boat, sailor, steamboat, sail...etc.

3. Words of french belongings: Words used in administration, judiciary, school, politics, medicine, fashion. French words are part of terminological and professional lexicon. We can mention some words such as:address, embassy, barricade, bureau, grant, bureaucrat.

.4.Words of latin and roman belongings albanian lexicon is full of latin words. Roman conquest in Albania lasted 500 years with a great influence of latin words.Gystav Majer supported the idea that albanian language is a "mixed" half-roman language.Terms of latin belongings are even in medicine, animal's names, body parts such as: agriculturist, child, hair, face.

5.Words of slavic belongings usually in albanian lexicon are from slavic and bulgarian language, entered in albanian language during the Medieval Age. Words of slavic language are used in agriculture, farming and handicraft: hammer, dab, punch, bone. There are some toponyms from slavic: Bistricë, Bogovë, Çorovodë, Novoselë.

6. Words of turkish belongings is included terminology of: clothing, urbanization, cuisine, administration. The earliest are words in war and clothing field such as: trumpet, linen, chest, cannon, drum,..etc. Words from other sources: nightingale, father, coffee, window, brandy, violet. There are also some arabian and persian words entered in albanian language through turkish language, thus we use the name orientalisms, with the main source from turkish.

\section{Lexicon and its classification}

In the outdate covering of lexicon are included: archaisms, historisms, barbarisms and neologisms. In this lexicon are included words that are no more used in linguistic accordance because of historical or linguistic causes but can be used for stylistic purposes archaisms and historisms .

Archaisms are outdated words almost out of usage, from active to passive part of lexicon. Archaisms are out of usage because there are new words to designate and those realie or occurance. Such words are up to date for such linguistic causes, are called archaisms. We have examples some words from earlier authors, we can't meet any more: përderësi "Iypësi-beggar", letërori "letrari-literary, shkrimtari-writer", përmjellet "zbardhet-lightened" etc. It's fair to call archaisms some word forms replaced later with other forms: "botesë" botim, "caktesë" caktim, "mësonjës" mësues.

Historisms are up to date words closely connected with the object or concept that we designate, related to certain historical,economical and cultural stages, meanwhile nowadays are used to prove that stage. Words such as :aga, bej, heshtë, kumbara, shqytë, vergji..etc. Objects or concepts that indicate historisms aren't used today, but are related to a past historical event and dissapeared to it. Outdated words are not part of standard language lexicon, but are used in literature for specific stylistic values. Historisms are used by writers to give a historical overtone to their literary work .E.x.: "Kështjella" of Kadare, "Kalorësi i Skënderbeut" of Haki Stërmilli.

Neologisms or new words (invented words). Continuous development of economy, commerce, transport, science..etc requires the language to complete its dictionary with new words, new expressions totally needed for economical political social and cultural purposes .In language neologisms are used to meet these needs. Usage of new words is stimulated for another purpose: in lexicon there are many word from excessive usage become outdated, to replace them, must invent new words.

Barbarism is from greek barbaros- stranger. These are words and expressions from no other language. These are called unnecessary borrowings. Although they can be used to characterize the characters for humour and satire, to create a context e.x. tiranda( krahoshe), two sta ban( këmbësheshtë), solucion (tretësirë), bulevad( shëtitore).

\section{Neologisms used in Faik Konica's works}

What can satisfy our curiosity, is knowing of some created words from Faik Konica's pen that has taken place in contemporary albanian dictionary. We can say there are a lot, but not as much as we would have expected. "We can bring an accurate list : anëtar, atdhe, atdhesi, atdhetar, bashkëqytetar, bashkëvendas, besëlidhje, ckishëroj, dëftesë, drejtshkrim, i cndershëm, gjuhësi, gjuhëtar, fushor, kombëtar, kryeartikull, nënshkrim, nërmjetësi, kushtim, paravajtje, përkujtesë, 
përvijësim, i tanishëm, themeltar, thellësisht, vetëqeverim, vetor, zyrtarisht". Some of these words, are used by Konica in a different meaning from nowaday meaning. These can be recreated later with new meanings,but the first inventor of these words remains Faik Konica as a phonological-morphological unit. Among neologisms of Faik Konica composites of nouns and adjectives has an important impact, as well as verbs and adverbs. These are composites with the first side nounhead krye-, as kryeartikull-headlines, kryefjalë-subject, kryepunë-main operation, kryeqytetar; and noun self-, such as vetëndjesë-self-feeling "ndjenjë", vetëqeverim-self-govern, vetëurdhërim-self-order, i vetëbotuar-self-published "i vetëshpallur" , i vetëqojtur, i vetëthënë-self-said; with adverb bashkë-, such as bashkëqytetar, bashkëvendas.

a. F. Konica enriched literary language giving new meanings to the well-known words, e.x.:he used anë-side in the sense 'parti-party', noun bushat he used in the meaning 'fermë-farm', cpik, 'shpjegoj-explain', drasë, 'klishe-cliche', lëkurë, 'diplomë universitare-academic grade', lojni, 'politikë-politics',rrëfim 'kuptim-meaning', rrëzë, 'origjinë-origin', sundimgovern, 'administrim-administration'.

b.Neologisms of F. Konica belong to the general cultural lexicon, but there is a great number of terms, such as avullorësi 'fleet', i dielluar (sunny day), dreqtmpronjës 'lawyer', dritëshkrim 'photograph', dytare 'gjeografi 'geography', krye 'capital', kryefiqal 'major official'.

c. F. Konica has given a great contribution in the terminology of linguistics. He has invented almost 30 terms in this field. It's worthy mentioning drejtshkrim-orthography, gjuhësi-linguistics, gjuhëtar-linguist, letrarishte-literature, mashkullore-masculine, nyjë-article, i pazëshmë-voiceless.

\section{Lexical-semantic developments of turkish words in albanian language}

In analysis of turkish words in albanian language and their lexical-grammatical treatment there are included some words called 'orientalisms', etymology of which is related to persian and arabic language entered in albanian through turkish language.

Lexical- semantic developments of turkish words in albanian language are conditioned from internal and external linguistic factors. "To clarify more these developments we analyze turkish words: firstly,on the aspect of new word formation based on the theme or a word that origins from turkish, second,on the aspect of creating new meaning formation in these words"On the analysis of 4000 turkish words in albanian language we notice that new word formation based on a theme or turkish word is made through a) affixation, b) composition.

a) Most of affixation words constitute those with productive albanian suffixes such as e.x. from byrek-pie turkish.burek +tore =byrektore. All the used words. Al derived words based on this model constitute almost $60 \%$ of new formations that we analyzed so far.

b) Among formed words through composition, dominate those with determinant relation among one side derived from turkish and the other derived from albanian, such as e.x. hallvashitës 'a dessert-seller'(from hallvë + shitës). These composing formations constitute almost $30 \%$ of analyzing new words.

1) Derived words with albanian suffix -të, are adjectives that have in common component "lëndë", e.x.i bakërt tq. bakir. 2) Derived words with albanian suffix - shëm, adjectives the have in common component,"cilësi" e.x. i bereqetshëm, tq. bereket. 3) Derived words with albanian suffix-ar, -tar have in common the active component such as e.x.: daulttar tq. davul.4) Words that are formed with suffix $-0-j$, are verbs that have in common active component e.x.: cobanoj tq. coban. 5) Composite with the first part a turkish word, have in common the component "mjeshtëri", e.x:. teneqepunues, tq. teneke, bakërpunues, tq.bakir.

Semantic developments are derived from turkish in albanian with conative character.

a) with a noted overtone neglective connotation , e.x.: words: cirak, tq. cirak.

b) with a deteriorative and pejorative overtone, e.x.: asker, tq. asker, kallauz tq. kalavuz.

c) with mocking and ironic overtone, e.x.: myteber tq. muteber, tellall tq. telal, kadi, tq. Kadi

Turkish words have their belongings in contemporary standard albanian language, neither can be omitted, nor can be replaced in all contexts of discourse, as sometimes proceeded in wrong way. Fan Noli was right with his reserved attitude toward the omission of turkish words, in which A. Krajni says- he knew to use to get in depth-conversation"për të shtruar muhabetin vendce". This demostrates that between turkish and contemporary albanian lexicon are new connections, as well as other borrowings from other languages. "For this reason, the need for full replacement of turkish words must be seen and reviewed as a viewpoint inconsistent with contemporary linguistic reality ,even though there are no entries of new borrowings from turkish to albanian". Questionable remains the opinion " only a part relatively small of turkish have a great usage " , despite the fact that usage of historisms in initial sense, continue to be used in spoken 
and written discourse, in stylistic overtones. Based on analysis of lexical-semantic developments of words derived from turkish in albanian we can draw some conclusions :

1) Almost 4000 words derived from turkish, analyzed almost 500 served as a source of forming inside the albanian derived words, composites or reattached.

2) Semantic developments of derived turkish words in albanian show that in one part of them we notice new derived meanings in chain style, preserving as well the first meaning, or as historicism.

3) New words with albanian affixation or derived meaning in turkish have a broad usage in albanian language. Almost $85 \%$ of them have entered in standard language as terms.

4) Lexical-semantic developments of turkish are not only a result of relationships among languages in historical range, when they were in direct contact, but also a result of interaction for the need for languages to assimilate Albanian standard language and its system's abilities and opportunities for the assimilation of foreign element, forming new words in its own source etc.

5) New trends of Turkish in albanian show the importance and complexity of their lexical-semantic values and the necessity of their appropriate codification in dictionaries. Samara says: "There Is a need for redaction and publishing of a bilingual dictionary in our country (turkish-albanian and albanian-turkish), where should be reflected all lexical-semantic trends of Turkish in contemporary albanian ".

\section{Fund of italianisms in albanian language identified as balkanisms}

Lexical italian element constitute a great variety of foreign words in all languages of Balcan. "The need to have a look in italianisms in languages of Balcan we can notice during the hard work for conducting a study of italian borrowings in standard albanian". To identify the proper source of words derived from italian into the albanian, we should have a look at balcanic languages. Balcanic languages have been a reception of italianisms. New greek has a wide range of italianisms mediated from turkish, into serbian-croatian italian borrowings through turkish, as for albanian there is a great number of italianisms inherited through greek and turkish. The problem we face is complex with lexical element of italian language in balcanic languages . Common difficulties :

First, the difference between italian and latin element in language, where formal and phonological criteria is not complete.

Second, the omission of venetian derived words common with italian words.

Third, the difference between Italian and French words.

Last, the difference between direct borrowings from italian those infiltrated through balcanic languages themselves . In Albanian the addition of venetian words is infiltrated through historical events between Republic of Venice and other coastline countries in Albania during Medieval Age. . A great number of venetian words, even though partly or fully extended interbalcanic, are presented through phonological-linguistic units as a unmediator of venetian sources in albanian , such as e.x.: baticë < ven.bataizza, makarona <ven. macaron (tq. makarna).

About Albanian, based on phonology of lexical units, many words are identified as oblique Italian source, and direct greek and Turkish . Kallo <it. Callo, kanellë <it. Cannella, salcë <it. Salsa. Based on Italian sources intermediated from Turkish are units such as: barbunjë <tq. barbunya <it.barbone, gardian <tq.gardian <it.guardiano, pupë <tq.pupa <it.poppa.

In Albanian, it's not so easy the distinction of direct source of a wide range of italianisms. It is supposed an Italian and Turkish influence in the words, such as : balsam (it. Balsamo, tq.balsam ), biletë (it.biglieto, tq.bilet ), pandispanjë (it. Pan di spagna, tq.pandispanya). Based on this category of words as well as the viewpoint of semantical field that they represent based on its influence is configured in a regressing scale , , terms detarie: balena, barkë, busull , kallamar, timon, vapor, etc. Words that indicate clothing and accessories: bastun, fanellë, fustan, kordelë, portofol, rrobë etc. Designations of house: ballkon, banjë, barakë etc. Terms of war: batare, bombë, patërshanë etc. Terms of public life: avokat, biletë, kancelar.etc.; designations of plants and animals: bizele, fazan, kanarinë, limon, sallatë..etc.; designations of games: as, damë, fant, pat..etc.

We see a rich variety of a great Italian influence into balcanic languages more than it's confirmed from scholars.

Last, Kristina Jorgaqi says: " ... the case of Italian element in Balcan languages, is seen in a profound way, not only for special languages, but also in contrastive plan , remains a research work of great interest".

Investigations about the way of features and peculiarities of infiltration of italianisms in such languages, so far are not completely shown in their completeness.

\section{Some issues about identity of phraseological units}

A fundamental problem that arises in general in phraseology as well as in practice of design of a phraseological dictionary is the determination of identity of phraseological units. To give the corpus to phraseological units of language , 
and to determine their lexicographic treatment first must be identified the content of linguistic phraseology to be distinguished from other units.

a) Phraseological unit is created as a designate sign with a certain specific aim in semantical-functional relatioships .

b) The entire character of meaning is associated with general characteristic and grammatical units of phraseology, in certain terms of phrase.

c) Phraseological unit has features of a linguistic unit with its own functions .

d) Phraseological units are completed linguistic units, thus can be identified and omitted in course of discourse,as well as word.

Identity and boundaries of phraseological units separate them from similar structures and units to them.It is used the axe phraseology- nonphraseology. In nonphraseology there are similar units with phraseology and not such with different features.

a) Nounphrases, where the same word has a literal meaning conditioned in a certain relation of words such as : dog life, childish behavior, genjeshter me bisht, jetë rozë. This is in the function of a determiner and adjectival structure.

b) Nounphrases, of verbal model as equivalents of unified lexical meanings are used in special words, such as: arrij fitoren- fitoj-win, kam shpresë- shpresoj-hope, bëj pushim- pushoj-resting. Every word maintains its autonomy, lexical meaning i.e., word features.

c)Nounphrases formed in the repetition of the same word or words of the same root, where the second part is appart from a lexical unit with it all features, whereas in the functional way we can notice a reinforcing part, such as : trim mbi trima, keq e më keq, plot e përplot, u lodha e u stërlodha.

d) Proverbs and wise words.Proverbs are sayings structurally organized as phrases with closed affirmation, such as : s'ka tym pa zjarr, ç'hedh në det e gjen në kripë, ujku ujkun se ha.Neither proverbs, nor wise words cannot be prototypes of phraseological units, but from proverbs can be gained phraseological units ( ujku qimen e ndërron, po zakonin e vjetër s'e harron).

e) Terms and complex designations can have a full clear direct meaning (truri i vogël, poli i Veriut) and literal meaning, motivating directly from meaning of its parts, ( Kashta e Kumtrit, ballë kazani "rakia e parë").

f) Literal expressions "fjalët fluturake", such as : i zbres yjet në tokë, furtunë në gotën e ujit and other literal expressions in artistic literature .

g) "Phraseological clauses " constitute an ambiguous category as well. These structures have a literal meaning as phraseological units, that in linguistic field are equivalents of clauses, such as : njëri i bie gozhdës, tjetri potkoit "cannot deal with each other", punë, punë natë e ditë që të shohim pak dritë; feja e shqiptarit është Shqiptaria.

h) Identity of phraseological unit is related to the case of partial boundaries of this unit. "Boundaries of phraseological unit are determined with constructive elements separated with purely syntactical relations with contextual elements, even though the latter is interinflected through the first elements ". Contextual interinflected elements are pronouns, also other parts of speech can be related with one part of phraseological unit ( $\mathrm{e}$ ka vënë p u n ë n në vijë).

i) Identity of phraseological unit is related with other occurrences of phraseological system :

-Nominal phraseological units, derived from verbal model, with the first part a suffixed verbal noun ( dhënia llogari, from jap llogari).

-Adjectival phraseological units, derived from verbal model, with the first part a participle noun ( $\mathrm{i}$ bërë bishë, from bëhem bishë).

- Adverbial phraseological units, derived from verbal model, with the first part a participle anticipated with a preposition ( pa lënë gjurmë, nga lë gjurmë). - Verbal phraseological units, derived from verbal model, with the first part a reflexive verb ( $u$ bë lëmsh, nga e bëri lëmsh)

\section{Albanian language as balcanic language}

Balcanisms haven't had the same extent in all over the languages of Balcanic Peninsula. We find them more in albanian , romanian, macedonian, bulgarian and greek languages. Balcanisms attracted the attention of many scholars. The first scholar that brought into light common features of balcanic languages was Jernej Kopilar. There is almost no balcanism, that we cannot find in albanian language. Balcanisms are present in all subsystems of albanian and other balcanic languages: in dictionary, in phonetic system and in grammatical structure. The presence of a great number of outdated common words almost 60-70 for albanian and romanian such as: i bardhë : barzë (lejlek); bredh: brad, brez : (dash). Scholars admit that these words are inherited in albanian language. It's of great interest the presence of a great number of phraseologisms in albanian language as well as in other balcanic languages : $\mathrm{E}$ di ujë, romanian $\mathrm{O}$ stiu ca apa, greek To ksero san nero, bulgarian Znam go po voda. Balcanisms, can be noticed mostly in the field of grammar. Amongst 
the most typical balcanisms is the post-position of definite article in albanian, romanian, bulgarian and macedonian e.x: albanian djal-i, vajz-a; romanian baiat-u-l, fat-a, bulgarian mladezh-ët, devojka-ta...etc. Two remarks about balcanisms:

First, should be emphasized that source of this phenomena cannot be required in those languages, when it appeared relatively too late, as in case of bulgarian and macedonian.

Second, this phenomena, from syntactical perspective shouldn't be seen as separate from rules of word order in balcanic languages. Post position of definite article in balcanic languages cannot be a source of bulgarian languages as it might been thought from any foreign linguist.

In albanian language post position of definite article is an ancient phenomena of this language in full accordance to its priority relatively ancient to post position all determiners of the noun. Another common phenomena of balcanic languages is the model of future tense formed with auxiliary verb $<<$ dua $>>$, which in most cases is petrified, thus transforming into a grammatical format e. x.: compare: do të bëj, gr.: tha kano, bulg. shte pravja, mac. qe pravam, romanian voiu face, serbian croatian cu delati. As for albanian language, it must be considered future model with format do, followed by the simple present tense of subjunctive,is all over the language system .

A common phenomena of balcanic languages is the usage of subjunctive mood in cases where other indio-european languages it is used the infinitive or other unexplicated verbal forms . e.x.: compare: dua të bëj, greek thelo na kano, bulgarian iskam da pravja, macedonian sakam da pravam, romanian voiu sa fac. Some linguists have supported the issue that this is an indipendent trend at least in some languages of Balcan. Last, it's worthy mention another syntactical phenomena in albanian,romanian,greek,macedonian,bulgarian,and in some other spoken sud serbian languages. Reclaiming of the(direct-indirect) objects through short forms of personal pronouns. This phenomena is benefitted through some west roman languages such as spanish and traditional italian. The direct object as well , is expressed in a full form of first and second personal pronoun in these two languages and is repeated in a short accountable form of accusative case. e. x.: compare in albanian language: $E$ bleva librin. Bleva një libër. Këtë e di . Ti di vetëm këtë.

Some linguists have supported the thesis that source of this phenomena seeking in vulgar balcanic latin as argued further in thesis. "In this assumption it is clear that Albanian language has maintained the fundamental features characteristics for indio-european languages family (obviously with its evolutions), during its centennial evolution in balcanic region has developed some new features found in some other languages of the Peninsula ". During its historical evolution there are appeared some trends , that can't be found in no other indioeuropean language. "This overall evolution of language is based on internal rules that conditioned its development and its continuous perfection to complete better the continuous needs from a developmental period into another".

\section{About the clearness of albanian language and its attitude toward foreign words}

Mass media communication has great chances to be enriched with lexical words. The first impression is that there is a poorness of words and expressions even though this isn't completely true. This because of some reasons:

a) In media there is a wide usage of general abstract words and expressions that give an overtone to the text. e.x: çështje, problem, detyrë, realizim, arritje...etc. Not to forget some evaluative expressions: Kanë mobilizuar të gjitha rezervat e brendshme; Prodhojnë me cilësi të lartë; U janë përgjigjur gjithnjë e më mirë kërkesave; $E$ kanë vënë në qendër të kërkesave...etc.

b) There are included writings with special words of corresponding fields, but they are meaningless to the wide mass or readers, often taking distorting forms from journalists, and become difficult to understand even for elite reader.

Either for grammatical criteria ,or for lexical criteria we notice some repeating errors. e.x.: dedikohet is wrongly used for i detyrohet, premton for lejon, rrit for shtoj ..etc. The crucial case in these fields remains the conflict for the clearness of language. Many unecessary foreign words can be classified into two groups:

First, are words of general meaning, can be used in various areas even though many of them have the albanian equivalence because of careless usage e.x influencoj, aplikoj, eliminoj, evitoj, preciz, fenomen, aprovoj, prioritet, princip, determinues, distancë, dominim etc.

Second, in media and television it is used the technical-scientific terminology . e.x. journalists know a little terms of new formation derived from albanian language. Specialists believe that only foreign terms maintain scientific level . "Variety of foreign terms joined with foreign syntactical construction and difficult explanation, make a wide variety of texts meaningless, even for specialists ". 


\section{Synonymy as a richness of albanian language}

Synonymy as a linguistic phenomena is related to semantics as a cause of human activity in the process of making sense of the world. Synonyms designate nuances and semantical peculiarities and coexist with other main words that define the same or similar object or phenomena. The reason for appearing synonyms in language, as well as other linguistic phenomenon, is a continuous development and difference of language. This difference stimulates new meanings and new overtones. Synonymic words in unconscious way try to be distinguished in a determined meaning. Definition of synonyms is determined in various ways from many linguists : "synonyms are words with lexical meaning, and change only through modifications of meaning, through expressive colour for the fact that belong to this or that stylistic level of language". A definition that we often see in linguistic literature is this: different words from sound composition in similar or same meaning. There are no absolute synonyms in language. Such considered are double lexical created from lexical units of various linguistic levels: e.x.: vajzë- gocë, çupë, çikë, vashë; treg-pazar ; fshat -katund; oratori-gojëtari; inspirimfrymëzim etc.

Distinctive scale of full synonyms depends on their usage related to the style and discoursive situation . The range of created synonyms in these linguistic conditions raises a great interest for the study of word semantics . e.x:. liken (mjek.) - urdhje, abort, (mjek.) - dështim etc. Synonyms with the same meaning we mostly face in field of terminology. The number of synonymic units of this kind is great in Albanian language. The genuine synonymy is seen in categorical grammatical nouns as designative units. There is a wide range of synonyms: bregc - balil- brojcë- zog, bletë- gargull- treckë- trishtiltrinckë-tringecë etc. Partial synonyms represent a great linguistic richness. Their meaning constitute distinctive meaningful emotional nuances, whereas genuine synonyms are a source of linguistic phenomena called diglossia (diglosi). Usage of synonyms constitute the richest and the most diversity of language :the more synonyms in language, the more richful it becomes. Synonyms have a great usage in all discourse fields. This usage is associated with fundamental functions: 1.Function of exchange, when it isn't needed replacement of the same lexical unit, 2. Function of the appropriate determination of thought, notion. 3. Expressive-stylistical function. These functions determine the character of synonyms and their wide usage in language. Meaningful relations of equivalence and similarity are better represented in synonyms. Synonyms in literary context of this verse i: kaloj, kaptoj, kapërcej, hedh,ose hidhërm, zemërim, pikëllim, trishtim. Example: "Kaluam male, hodhëm përrenj, kaptuam gryka, po urinë se kapërcyem dot as lodhjen". Synonymy as a rich source of language and synonymy as a richness of expressions in language is considered very important aspect of linguistics in general,as well as an important aspect of aesthetical discourse in general .

\section{Antonyms in school}

Antonymy is a general linguistic phenomena that expresses semantic relations through words in opposite sense. Antonym words , that designate objects or phenomena, are very closely connected to the semantical aspect, e. x.: in pupil's mind is bad someone that is not good, meanwhile is bitter something that is not sweet. Denial of the same part of antonymous couple reminds us its opposite. Main classes and groups of antonyms in albanian language, their great richness and diversity, come up in word pairs in opposite roots and themes (such as: good-bad i mirë-i keq,give-receive jap- marr), with suffixes ( i pastër-i i papastër,clean-unclean, kamje- skamje,wealthy-poverty), in paired compound and complex words (gjakftohtë- gjaknxehtë, paradite- pasdite). The scale of contraposition can change inside the same structural feature of antonyms: e.x.: in pair hot-cold i ftohtë- i ngrohtë, because adjective i nxehtë-hot(= shumë i ngrohtë) scores a high rating scale of temperature than the adjective warm- i ngrohtë. "Forms of exercises about antonyms in school are better, but they must be complemented with other new forms to get deeper in semantics of words and multiple relations of meaning amongst them, because antonyms constitute a specific micro-system of lexicon ".

There are three main categories of antonyms: a)antonyms of words that contrast all their senses such as : mirë- keq, b) antonyms of words such in some of their senses, e.x.: too cold ,full of frost. c) antonyms of words such in specific contexts , e.x. he was full of joy, he was full of anger.

\section{Comparings and contrasts of albanian language with other indioeuropean languages}

Dividing the richness of words in albanian language from borrowings, after a contrasting analysis of phonological system of some lexical elements, this scholar puts the albanian language in a special place, worthy in subsequent lines . Albanian is a northern-eastern indioeuropean language . According to Çabejt: "Indioeuropean languages are distinguished as western( language kentum)and eastern ( language satem), according to the criteria of training gutuals k', g'". In northern indioeuropean languages short letter 0 - is opened into an a. Another ranging criteria creates circumstances that albanian letter $\mathrm{f}$ - of latin ph- of greek correspond in words of the same source with one b. Noticing that albanian language belongs to eastern indioeuropean languages, and northern indioeuropean languages and on the other side its $b$ - with most of 
indioeuropean languages, in its phonological system, and in general linguistic system is far from two classical languages, greek and latin.

Indioeuropean character of albanian language must be seen in the perspective that, not the overall aspect of its linguistic richness derives from the ancient fund of indioeuropean world. Based on the tireless efforts of albanian population with other populations during its history, albanian language has had a huge lost in its authochthonous inherited depository, and on the other side has taken various features from other languages that sorround it. One of main tasks of historical linguistics with a comparing analysis must emphasize one of the coverings of foreign element from inherited linguistic fund . Forms of flexibility: plak- pleq, from plaki. From lexicon we mention some words: ujk, ulk, lat. lupus, greek. likos.

Nor the whole richness of Albanian is inheritance of medieval indioeuropean period. Like any other language, Albanian language has created words from its own subject, which are not foreign,anyway relatively new . During a period of linguistic history it appears a period that includes development of language in its historical age.Based on the relations between Albanian and two classical languages of antiquity in the Middle Ages, very well-known languages of that time, it comes into light the history itself of that language. Saying that inside the indioeuropean territory, Albanian is closely related to this territory such as latin,greek,roman,Italian,French Slavic, Turkish, borrowings treated later on a broader context . With long coexistence of Albanian language with other populations of Balcanic Peninsula,Albanian language prospered along with languages of such new features common with balcanic order.

\section{Chronology of borrowings in albanian language}

\section{The oldest setting of borrowings}

In XVIIth century has begun a new age of contacts relationships between turkish and albanian. This was exposed by Andokli Kostallari, factors that determine fundamental features of such relationships in that period were firstly,changes made in this century in economical- social-ideological-cultural life of albanian cities. This background was reflected into albanian lexicon, where turkish borrowings ranged into the highest ratio. Many turkish have entered in albanian in twothree previous centuries. Collected materials still don't permit us having a full exhaustive picture of such linguistic influence in first or second period. Based on research we made, we can bring some data, which lead into a clear idea about the rhythms of this process.

\section{Conclusions}

Among the main issues we discussed above, we draw the conclusion that we can't pretend that literary standard albanian language being pure without the influence of globalisms. We have a rich fund of globalisms, thereby albanian language can't avoid 100\%. We can't speak about categorical way,that borrowings of indioeuropean languages are $100 \%$ harmful or $100 \%$ beneficial. We admit they enrich our language, but at the same time "impoverish" it, because we have our equivalent words in a greater sense. The direct influence of powerful languages and cultures represent a great challenge firstly in its own lexicon. Influences among languages are as ancient as languages themselves. Albanian language has survived under such influences. The most influent part from internal and external linguistic pressures is lexicon and linguistic changes in lexicon. Nowadays in albanian language are mostly inserted the anglicisms. Albanian language as other languages accept foreign lexical elements, translates them, adapts them,assimilates them, and creates neologisms with them. According to the scholars in this field, foreign words don't put in danger the corpus of received language .

\section{References}

Çabej, E. "Introduction into the history of albanian language ", Prishtinë, 2008

Demiraj, Sh. Albanian as Balcanic language, in "Our language", Tiranë 1983/1

Islamaj, Sh. "Linguistic culture and aesthetical usage of language " Toena Publications

Elezi, G. "Linguistic inquiries and interpretations of Albanian language 1", Skopje, 2012

Memushaj, R. "Introduction to linguistics", Tiranë, 2006

Samara,M. Richness and pureness of language , in "Our language",Tiranë, 1982/2

Thomai, J. " Lexicology of Albanian language", Tiranë, 2011

Thomai, J. , Lafe, E. Samara, M. "Philological studies Nr. 1-4, Tiranë 1995 